\title{
Problems with the Word Made Flesh: The Great Tradition of the Scientific Revolution in Europe
}

\author{
Harold J. Cook \\ Brown University \\ Harold_cook@brown.edu
}

\begin{abstract}
The Great Tradition of writing about what came to be called The Scientific Revolution developed in the mid-twentieth century and helped to shape what came to be termed "early modern" Europe. At least two fundamental structural elements of the framework were that a small group of independent minds had been set free to grasp new truths, and that rivalries among many groups in Europe never allowed "European civilization" to achieve homeostasis, thus continuing to encourage innovation in conditions of freedom. It is worth noting, however, that the first of these structural elements had religious overtones that were important in the early stages of the Cold War, and that the second placed innovation within a tradition of great texts rather than material culture and practice. Both changed the earlier conversation of the 1930s, which had been about political economies, connecting the new history of science to a history that offered to explain European superiority on the basis of the search for truth. Recent developments in global history, which are rooted in economic histories, challenge such a framing. The brandname of The Scientific Revolution is common and will remain a useful short-hand, but its meaning requires major revision and should not be limited to the history of Europe.
\end{abstract}

\section{Keywords}

Scientific revolution - religion - economies - civilization - global history - historiography

The subject known as The Scientific Revolution remains endlessly fascinating. The term became a commonplace even before I was born, so in my opinion there is no point in trying to alter it. It says something about a historical period that, however simple-minded, continues to attract interest. In an age 
anxious to find brand identities for everything there seems little to gain in simply abandoning the term, however problematic it has become. Over the course of my academic career I have consequently simply aimed many of my contributions at support for the position that the scientific revolution is an aspect of a period known as the early modern period. My own line of investigationshared by a subset of those identifying themselves as historians of science- - has been to explore evidence found among the remains of the medical community and their patients: the extant documentation for such studies is rich, touches on the lives of all kinds of people, and sheds light on the informed (and uninformed) responses to changing ideas and practices in the period. Furthermore, the powerful observed effects of the medical marketplace on aspects of the new science led me to explore the causal powers of politico-economic history, and from there to launch into studies of the connections between European events and changes elsewhere in world. Those concerns have made me even more attentive to questions about institutions, material life, and "translation" writ large. But that has taken me far from what Floris Cohen has aptly termed The Great Tradition, which sees The Scientific Revolution as a historical transformation of the human spirit that occurred in Europe alone. ${ }^{1}$

I have long understood The Great Tradition (from which I have long differed) to be framed by a sense of the history of science as providing evidence for a movement in the human spirit toward enlightenment, a view laden with religious overtones. The religious framing may seem odd given the Positivism of George Sarton and other founders of the field, and given the loudly self-professed atheism of many contemporary scientists themselves, Richard Dawkins most prominent among them. But a slimmed-down version of how the gods created worlds from their heads - as in the bowdlerized report that Minerva simply emerged from the head of Zeus-remains powerful. Many practitioners of science, medicine, and technology themselves, especially those brought up in high-pressure worlds focused on finding funds for expensive laboratories, often esteem notions of intellectual brilliance. While the routines of laboratory work can be unexciting, those in command of them, acting in alignment with meritocratic ideals, often see their job as identifying great minds and supporting their work. The studies of historians who seek other kinds of causalities may be read with interest by scientists and practitioners who are dissatisfied with their own communities, or who observe the daily effects of social, economic, and institutional structures on those they are trying to help. But a large body of opinion remains concerned with identifying and rewarding innovation, which, despite work in the social and cognitive sciences, is

1 H. Floris Cohen, The Scientific Revolution: A Historiographical Inquiry (Chicago, 1994). 
often held simply to emerge from minds engaged with great ideas. The views about personal brilliance continue to make for difficulties when, for example, historians seek to understand developments that include "practical" subjects like medicine and technology, or "classificatory" field and museum sciences, or aspects of "non-Western" knowledge. But ideals about Mind over Hand dominated when the history and philosophy of science came to be established in the United States in the twentieth century.

In the later nineteenth and twentieth centuries, emulating German practice, the field of history of medicine had become active in many medical schools; a handful of academics, such as George Sarton and Charles and Dorothea Singer, similarly explored the history of science and technology. Most of the early work was self-consciously positivistic, following Auguste Comte in seeing the establishment of a "positive" knowledge of nature as a further step in civilization's progress beyond ignorance and superstition toward a government of Reason. On such grounds the warfare between science and religion became famous. Moreover, in a Gilded-Industrial age of intensive military and colonial rivalry, few disputed the proposition that the natural sciences and their instrumental-technical methods established irrefutable facts and worked out how the "mechanical" operations of nature produced worldly regularities and the derivative instruments of power. The chief scientific method was generally held to be inductivism, urging practitioners to launch investigations meant to acquire empirical information of all kinds, or to sort through it to discover patterns. The principles of positivism also supported plans for collective material improvement, from projects sponsored by states and industries, to utopian, socialist, and industrial communitarianism, to revolutionary communism. In reading the literature produced by the historical positivists, one may now bridle at their mockery of various "superstitions" and "backward" historical traits, but one also notes the universalist vision of human progress and the inclusiveness of many fields of knowledge-making, including medicine, technology, philology, and others under the rubric of science.

But the professional classes, who worked with the growing mountains of paperwork in the offices of government, industry, and finance, were speaking up, too, and worrying about materialistic disorder and corruption. Following the terror and ruination of the First World War and the threat of political revolution, they found their answer in one of their own - an official from a patent office-who overthrew the established sense of three-dimensional mechanism in favor of grand non-Euclidean ideas few could understand: Albert Einstein. The announcement of the experimental confirmation of Einstein's Relativity Theory by Sir Arthur Eddington at a meeting of the Royal Society on November 6, 1919, appeared in the Times of London as a "scientific revolution," 
apparently the first use of the term. Einstein himself soon became a great, and peace-loving, celebrity. ${ }^{2}$

The revolution in physics provided an example of a new and creative order based on imagination rather than labor at a moment when godless Bolshevism threatened radical disruptions. This was also the moment of Max Weber, who established an anti-positivist and anti-materialist social science that took relationships of meaning (including religions) and their institutions to be fundamental. The "deductive" implications of mental insight therefore quickly replaced the ideal of inductive labor in nature's vineyard, allowing science to step firmly into religion's shoes as a means for establishing creative order in the universe during a revolutionary age.

A decade after Eddington's announcement at the Royal Society, the mathematician and philosopher Alfred North Whitehead recalled what it had been like to be present at the revolutionary event, with a portrait of Isaac Newton looking down on the scene as his older "great adventure in thought" was replaced by a new one. Whitehead admired aspects of the older science, which he characterized as "scientific materialism," but he thought it "entirely unsuited to the scientific situation at which we have now arrived." In a moment when grand ideas proliferated, "If science is not to degenerate into a medley of $a d$ hoc hypotheses, it must become philosophical." The historical philosophy he went on to outline might best be called metaphysical, with the chapter titles in his Science and the Modern World (1927) moving from the "Century of Genius" to "God," "Religion and Science," and finally "Requisites for Social Progress." In that lineage, "The Reformation, for all its importance, may be considered as a domestic affair of the European races.... Since a babe was born in a manger, it may be doubted whether so great a thing has happened with so little stir." Post-Einsteinian science had at last become God's logos: "And the Word was made flesh, and dwelt among us" (John 1:1-14).

The interwar period saw many historians of religion turn their attention to the origins of the metaphysical transformation of the understanding of the world. ${ }^{4}$ For instance, when Alexandre Koyré wrote of "the scientific revolution" in 1935, he did so as someone educated in late medieval philosophy and as an advocate

2 Richard Rhodes, The Making of the Atomic Bomb (New York, 1988), 169; Alastair Sponsel, "Constructing a 'Revolution in Science': The Campaign to Promote a Favourable Reception for the 1919 Solar Eclipse Experiments," British Journal for the History of Science 35 (2002): $439-67$.

3 Alfred North Whitehead, Science and the Modern World (Cambridge, 1927), 13, 22, 2.

4 For instance, Edwin Arthur Burtt, The Metaphysical Foundations of Modern Physical Science (Garden City, NY, 1954 [1924]). 
for the teaching of Hegel in the French schools: the history of science now helped to explain transformations of mind. ${ }^{5}$ It is also notable how firmly the sense of the new science of the day was rooted in mathematical physics. Whitehead was himself a mathematician, and Koyré would later become best known for making a strong case for science arising from "the mathematization (geometrization) of nature" and from no other source. ${ }^{6}$ Those who had approached the history of science as an inductive exploration of all of nature began to complain. For instance, the Anglican canon and historian of natural history, Charles E. Raven, would soon write in dismay that "To represent the history of science, as is done in almost all the text-books, as a papal succession, Copernicus, Kepler, Galileo, Newton, ... is only possible on the assumption that the important contributions are those which led up to the dominant mechanism and determinism of the late nineteenth century, and that the astonishing achievements of zoologists and botanists in the sixteenth and seventeenth centuries can be ignored." The framing of a Great Tradition for the newly identified "scientific revolution" would also relegate histories of medicine and technology to a secondary place, and to their own departments, journals, and meetings.

When a few years later the senior British historian, Herbert Butterfield, again mentioned "the so-called 'scientific revolution', his phrasing suggested that the label was becoming well known. Butterfield is most often remembered as the person who fought against (positivistic) progressivism in historical writingor Whiggism - but according to A. Rupert Hall he had been turned against his formerly "relativist" views in the war against fascism by Winston Churchill. ${ }^{8}$ Butterfield's The Origins of Modern Science (1950, based on lectures delivered in 1948) therefore took up Whitehead's language, famously saying that the formation of science "outshines everything since the rise of Christianity and reduces the Renaissance and Reformation to the rank of mere episodes, mere internal displacements, within the system of medieval Christendom." ${ }^{9}$

Similar views framed the post-war establishment of government funding for scientific research in the United States. As the Second World War drew to a conclusion the head of the Office of Scientific Research and Development (OSRD) set up several committees to help with the transition to peacetime,

5 See Charles Gillispie's illuminating entry on Koyré in The Dictionary of Scientific Biography.

6 Alexandre Koyré, Newtonian Studies (Chicago, 1968 [1965]), 6. His first major work argued for Galileo as a conductor of thought experiments rather than physical ones: Études Galiléennes (Paris, 1939).

7 Charles E. Raven, Natural Religion and Christian Theology (Cambridge, 1953), 7.

8 A. Rupert Hall, "On Whiggism," History of Science 21 (1983): 45-59.

9 H. Butterfield, The Origins of Modern Science 1300-180o, 2nd ed. (New York, 1960), 7. 
which were drawn into a debate about the nature of science. A fresh account of the arguments appears in a recent paper by Roger Backhouse and Harro Maas, who have examined the work of the committees that laid the foundation for the position paper produced under Vannevar Bush's name: Science, The Endless Frontier (1945). The committees chaired by James Conant (noted chemist and President of Harvard University) and Karl Compton (noted physicist and President of MIT) included members like the later Nobel Prize-winning economist Paul Samuelson and the founders of the departments of the history of science at Harvard and Cornell, I. B. Cohen and Henry Guerlac. Backhouse and Maas concluded that the post-war break between the fields of economics and history of science was a missed opportunity, since both would have benefited had they remained in conversation..$^{10}$ But the new metaphysical view of science won the day, causing them to go their separate ways.

The historians of science advising Bush were divided. Guerlac had spent the war working at MIT's Radiation Laboratory (for radar development), which was under the direction of Nobel Prize-winning Isaac I. Rabi, who considered that wartime control of industry by government and the appointment of salaried scientists based on merit worked well. Guerlac had also previously completed a Ph.D. dissertation in History at Harvard in 1941 on the development of science in eighteenth-century France as an aspect of interstate competition and warfare. ${ }^{11}$ But during the 1930s, inspired by Soviet examples (and the materialist positivism that underpinned them), British Marxist scientists had also been arguing for governmental support for their work. ${ }^{12}$ When Guerlac later wrote about the interests of the chemist and government official, Antoine Lavoisier, "in practical matters, such as street lighting," the Gaulist Koyré responded by labelling the point "un peu Marxist."13

Cohen, on the other hand, emphasized the conceptual aspects of science. He had been teaching crash courses in physics and mathematics for naval pilots, and he would later be awarded a Ph.D. in 1947 for his 1941 published edition of Benjamin Franklin's experiments on electricity. He would also come to work closely with Koyré on an edition of Newton's Principia, of which Cohen

10 Roger E. Backhouse and Harro Maas, "A Road not Taken: Economists, Historians of Science and the Making of the Bowman Committee," Isis 108 (2017): 82-106.

11 Henry Guerlac, "Science and War in the Old Regime: The Development of Science in an Armed Society" (Ph.D. Diss., Harvard University, 1941).

12 Gary Werskey, The Visible College: A Collective Biography of British Scientists and Socialists of the rig3os (London, 1978).

13 Quoted in Mary Jo Nye, Michael Polanyi and His Generation: Origins of the Social Construction of Science (Chicago, 2011), 241. 
wrote: "In Newton's achievement, we see how science advances by heroic exercises of the imagination, rather than by patient collecting and sorting of myriads of individual facts. Who, after studying Newton's magnificent contribution to thought, could deny that pure science exemplifies the creative accomplishment of the human spirit as its pinnacle?"14 Cohen therefore fell in behind the two senior science administrators on the committees, Conant and Compton, taking the view that science had its apogee in the "pure" intellectual investigations of "free men."

Bush's report consequently concluded that pure science needed to be kept apart from government decision-making and the political forces that shaped them. ${ }^{15}$ Science was therefore to be compared not to the processes of material betterment but to philosophy and the fine arts, often drawing on the example of the shared musical interests of many of the scientists from haute bourgeois Central Europe, being a creative expression of individual minds. The structure of the new high-status National Science Foundation was intended to insure that through the peer-review system the scientific aristocrats of elite universities would maintain control of science funding, at least insofar as the nonroutine aspects of scientific work were concerned (the latter were funded through other kinds of governmental institutions). The NSF also established a special granting program for research in the history and philosophy of science, which supported many of the new departments being established in the field. In the post-war period that subject was therefore led by academics who argued for a lineage of pure scientific thought, developed by a scientific brotherhood who were set apart from worldly entanglements. By the end of the 1950s, even Guerlac described his two-semester course in the history of

14 I. Bernard Cohen, The Birth of a New Physics (New York, 1985 [1960]), 184; their most important collaboration was Alexandre Koyré and I. Bernard Cohen, eds. Isaac Newton's Philosophiae Naturalis Principia Mathematica, 3rd Ed. (London) 1726, With Variant Readings (Cambridge, 1972). For more on the importance of this form of idealism to postwar Free World ideology, see David A. Hollinger, "Science as a Weapon in Kulturkämpfe in the United States During and After World War II," Isis 86 (1995): 440-454; idem, "Free Enterprise and Free Inquiry: The Emergence of Laisse-Faire Communitarianism in the Ideology of Science in the United States," in Science, Jews, and Secular Culture: Studies in Mid-Twentieth Century American Intellectual History (Princeton, 1996), 97-120; Anna-K. Mayer, "Setting Up a Discipline: Conflicting Agendas of the Cambridge History of Science Committee, 1936-1950," Studies in the History and Philosophy of Science $3^{1}$ (2000): 665-689. 
science for engineering students as meant to convey "a sense of science as an enterprise of the mind." 16

A revolution in metaphysics and theory had therefore arisen in opposition to positivism. (I still sometimes hear historians of science attack positivism as if it remains the chief enemy for the field.) The framework of "the" Scientific Revolution offered a philosophically idealistic vision of fundamental change, one based not on political upheaval but on the minds of men, who understood God as rightly interpreted nature, promising material betterment while coupling it with spiritual improvement as well. The semi-religious aspects of the revolutionary mental insights of free men-associated with tacit knowledge, Gestalt psychology, and imaginative leaps —-were spelled out in the work of mid-century historians of scientific ideas such as Ludwig Fleck, Michael Polanyi, Karl Popper, Giorgio de Santillana, Alexandre Koyré, I. B. Cohen, and Charles Gillispie. They had their follow-on in Thomas Kuhn's scientific communities who proceeded in a series of incommensurable leaps from one paradigm to another. This conceptualist framework motivated The Great Tradition of The Scientific Revolution. ${ }^{17}$

But Whitehead's use of the phrase "the European races" is a reminder of other frameworks prominent in the early twentieth century. He was clear that science was a universal possession of humanity, for "its home is the whole world." But he also considered it to have been "born in Europe."18 And Europe was not just the home of the European races but of European "civilization," also thought to be uniquely marked out by science and technology.

After the horrors of the First World War and the growing independence movements in the European colonies, fears about the future of "Western civilization" proliferated. Columbia University and the University of Chicago pioneered courses in the subject to elaborate the common history of a "JudeoChristian" inheritance layered on top of a Greco-Roman one. Civilizations were therefore associated with core sets of ideas and ideals, allowing their programs to be built on the teaching of "great books." ${ }^{19}$ The word itself became prominent in many titles, as in an important new historical journal founded in post-war France: Annals. Économies, sociétés, civilizations. The much admired Marshall

16 Marshall Clagett, ed., Critical Problems in the History of Science (Madison, 1969 [1959]), 240.

17 Cohen, The Scientific Revolution.

18 Whitehead, Science and the Modern World, 3-4.

19 For a very helpful review, see Burke's commentaries in Marshall GS. Hodgson, Rethinking World History: Essays on Europe, Islam, and World History. ed. Edmund Burke, III (Cambridge, 1993). 
Hodgson of Chicago, author of the three-volume Venture of Islam (1974; the first essays appearing in 1961), defined a civilization as "interdependent and cumulative traditions" that express "values carried in lettered tradition," which in turn create continuities in "social and economic institutions generally." ${ }^{20}$ It is no surprise, then, to note that one of Butterfield's chief aims for the history of science was to use its narrative as a foundation for a more general "history of civilization." ${ }^{21}$ Butterfield's Scientific Revolution therefore helped to provide a key framework for the new study of a subset of Western civilization that was beginning to be called "early modern Europe" at a moment when NATO and the new European economic union called for continued Western unity against various non-Western menaces. ${ }^{22}$

Given the early twentieth century conviction that science was an assemblage of concepts, and that core concepts and ideals shaped civilizations, the question of why it was that The West possessed "advanced" science and others did not became a common question that could be put comparatively. Most famously, the biochemist and historian Joseph Needham brought the two terms together in his multi-volume Science and Civilisation in China (19542000), which asked why The Scientific Revolution had not occurred in China. Needham's early humble Christian socialism, overlaid by Marxist ideas of historical development that he encountered in the early 1930s, caused him to think that early China had possessed all the necessary components for science but did not achieve the breakthrough. During his service in China during the war he began to collect further personal experiences and information and brought his project back to Britain afterward, leading to his multi-volume study. ${ }^{23}$ Needham's own structural arguments were explicitly sociological and economic, borrowing from Weber via Bukharin and coupled with Wittfogel's elaboration of Marx's ideas of an "Asiatic" mode of production. ${ }^{24}$

Many historians of science noticed in Needham's invitation to compare civilizations a close alignment with the "cultural" or Weberian aims of The

$20 \quad$ Ibid., 85 .

21 Butterfield, Origins of Modern Science, 10.

22 Theodore K. Rabb, The Struggle for Stability in Early Modern Europe (New York, 1975), 13-14.

23 Henry Holorenshaw, "The Making of an Honorary Taoist," in Changing Perspectives in the History of Science: Essays in Honour of Joseph Needham, ed. Mikuláš Teich and Robert M. Young (Dordrecht, 1973), 1-20; Gregory Blue, "Joseph Needham, Heterodox Marxism and Chinese Science," in Science and Technology in East Asia: The Legacy of Joseph Needham, ed. Alain Arrault and Catherine Jami (Turnhout, 2001), 11-20.

24 Kapil Raj, "Rescuing Science from Civilisation: On Joseph Needham's 'Asiatic Mode of (Knowledge) Production," in The Bright Dark Ages: Comparative and Connective Perspectives, ed. Arun Bala and Prasenjit Duara (Leiden, 2016), 255-80. 
Great Tradition. Floris Cohen, for instance, admired Needham's work although not his Marxism, concluding that Needham's most important suggestion had been that the natural state of any society is "homoeostasis" whereas Europe exhibited "instability." That contrast, Cohen enthused, "teaches us more about the environment in which the Scientific Revolution became possible than any other I have ever come across," while it also showed that Needham "belongs to the West." ${ }^{25}$ In a later summary of his views on Needham, Cohen reiterated that one of Needham's most "precious insights" was about "Chinese homoeostasis and European dynamism," the latter "setting the world on the path toward modernity" in large part because of "the seminal contribution made by modern science and its (at least on the face of it) miraculous rise in Europe in the first place." In the end, then, Cohen used Needham to argue that Europe became scientific from the inherited Greek legacy which, due to various "dynamics" prompted by its philosophical "activism," framed "that decisive event in the history of humankind, the rise of modern science." ${ }^{26}$ Or, in Toby Huff's formulation, the unique "curiosity" of The West explains why it "experienced a singular scientific and economic ascendancy of at least four centuries." ${ }^{27}$ One can certainly find plenty of other accounts that attribute the rise of European "economic premacy" to the "triumph" of European science and technology that emerged from a conceptual "scientific and humanistic revolution." ${ }^{28}$

The legacy of The Great Tradition, then, offers powerful reasons for why The West came to dominate The Rest. The Rise of Science in Europe remains near the front of arguments about what is needed for international development as well as comparative posturing, and remains an active publishing arena, as represented by recent works like David Wootton's and Steven Weinberg's, which are circulating widely from very large trade houses and well-placed

25 H. Floris Cohen, The Scientific Revolution: A Historiographical Inquiry (Chicago, 1994), 462; for the section on Needham, see esp. 439-482.

26 Cohen, "Joseph Needham's Grand Question, and How to Make it Productive for Our Understanding of the Scientific Revolution," in Science and Technology in East Asia, ed. Arrault and Jami (Turnhout, 2001), 29, 31. For an elaboration of his historical views, Cohen, How Modern Science Came Into the World:Four Civilizations, One 17th-Century Breakthrough (Amsterdam, 2010); in his popular study, Cohen again refers to the special characteristics of European "openness," "curiosity," “energy," “individualism," and “judgement”: Cohen, De Herschepping van de Wereld: Het Onstaan van de Moderne Natuurwetenschap Verklaard (Amsterdam, 2008), 267.

27 Toby E. Huff, Intellectual Curiosity and the Scientific Revolution: A Global Perspective (Cambridge, 2011).

28 Geoffrey C. Gunn, First Globalization: The Eurasian Exchange, 1500-180o (Lanham, MD, 2003), 7-8. 
reviews. ${ }^{29}$ Wootton writes that "modern science was invented between 1572 ... and 1704" in Europe, being "a single transformative process," which he places firmly within The Great Tradition: for instance, while he gives a short account of the anatomical study of Andreas Vesalius he places it in a chapter on "The Mathematization of the World." Moreover, in raging against recent historical "relativism" he notes and criticizes the strong anti-positivism of Thomas Kuhn and most of those in the field since then, but he fails to identify their sources or interests, lumping together many of the recent historiographical and philosophical positions. ${ }^{30}$

The Great Tradition of The Scientific Revolution is not only still being written, however, it is still accomplishing much work in the current revolution in funding in the United Kingdom, in language that would have been familiar to Conant and Compton, justifying moves to shift all remaining government research budgets into the natural sciences, especially into the biomedical fields. ${ }^{31}$ I remember from my time in Britain during the first decade of the

29 David Wootton, The Invention of Science: A New History of the Scientific Revolution (London, 2015); Steven Weinberg, To Explain the World: The Discovery of Modern Science (New York, 2015).

30 Wootton, Invention of Science, I: 183-6, 586.

31 For instance, consider this announcement of a talk by the then soon-to-be chief science adviser to the British government:

"The Collision of Science and Culture: C. P. Snow revisited".

by Sir Mark Walport, Director, The Wellcome Trust.

Date: Monday ist November 2010.

$\cdots$

"In his famous Rede Lecture of 1959 C. P. Snow lamented the 'gulf of mutual incomprehension' that had developed between the 'two cultures' of science and the arts. The gulf can still be found today and many institutions still exist in monoculture. Huge creative and cultural insight can be achieved by the collision of the cultures. The Wellcome Trust believes that initiatives combining the two cultures are an effective way of stimulating debate and engaging people with biomedical science. Visual art, music, moving image, creative writing and performance can all reach new audiences that may not believe themselves to be interested in science and provide new ways of thinking about the social, cultural and ethical issues around contemporary science."

"Collaborative and interdisciplinary practice across the arts and sciences can help to provide new perspectives on both fields. The arts can also provide imaginative ways of engaging and educating young people in the field of science."

C. P. Snow was also cited in light of current funding battles:

https://www.theguardian.com/education/2015/mar/29/war-against-humanities-atbritains-universities?CMP=share_btn_tw (accessed May 25, 2017).

For some impression of the consequences: 
twenty-first century that the chief term of denigration for work in STS and the history of science that tried to problematize the master narrative was "relativism." It was an accusation that became a source of jocularity at the time of the "science wars" of the 1990s, and as Wootton's book shows, remains in use. One of the expressions of contempt, Higher Superstition (1994), argued that the "academic left" had simply left the path of reason in its quarrels with the view that science was the highest cultural expression of great truths.

It is perhaps ironic that the Old Left of the early twentieth century was so powerfully inspired by Marxist materialism and Positivist progressivism, aligning much better with the current assumptions of the anti-relativist scientific community. It is true that the New Left began to privilege ideology and then cultural studies, which to the untrained eye can sometimes seem arcane, relativist, and effete. But in recent years studies of sт M have been trying to reunite hand and mind by examining practices as prior to concepts. ${ }^{32}$ We certainly need not be relativistic about the phenomena established by STм investigators, nor should we simply revert to positivist efforts to rise above the study of the interests and meanings of the human world that produced them. ${ }^{33}$ The entangled subjects of science and society are best analyzed not through attending to the concepts they produce but by investigating the underlying processes from which they both emerge.

In short, the priests of the temple of high theory remain eager to accept offerings. Modern life is impossible without the work produced in their name. Their budgets consequently come mainly from the public purse, supplemented by charitable giving, and depend on justifications about international power, competitive advantage, and material improvement. Other priestly castes live from profit on sales of their often beautifully-packaged high-tech products. But the importance of such groups among us is an invitation to revisit the road not taken in 1945: the interdependence of sciences and political economies, which has long been in the forefront of the minds of war planners and development experts. That study in turn further enables us to see the possibility of materialist histories of practices built by both hand and mind; and the study

http://www.timeshighereducation.co.uk/news/cuckoo-managers-are-throwing-outacademy-traditions/2020315.article\#.VV3gtjyo7CA.twitter (accessed May 25, 2017).

32 Bruno Latour and Steve Woolgar, Laboratory Life: The Construction of Scientific Facts (Princeton, 1986); the first edition, of 1979, used the subtitle "The Social Construction of Scientific Facts," but by the mid-1980s a conflict between the sociologically-oriented and "actor-network" positions had opened up and the word "social" was dropped.

33 Bruno Latour, An Inquiry into Modes of Existence: An Anthropology of the Moderns (Cambridge, MA, 2013). 
of "how" rather than "why" in turn opens up possibilities for exploring some of the connections that allow people, practices, and concepts to move about the world rather than remaining confined within imagined nation-states or civilizations. ${ }^{34}$ A criticism of such studies is often advanced: that they are "flat" histories without a sense of the centers of power. But in fact they can help us see how power has been produced, exchanged, and accumulated on the basis of material as well as meaningful substances. ${ }^{35}$ Perhaps the process in view is not so much like the birth of a babe as like transubstantiation. Our historical work requires attention to emergent transformations in body and spirit together rather than to sudden revolutions in minds alone. We can continue to use the phrase The Scientific Revolution, but it continues to need redefinition. It has no simple history, nor a single homeland. There is much work to do.

34 Indicative recent examples include: Sanjay Subrahmanyam, Courtly Encounters: Translating Courtliness and Violence in Early Modern Eurasia (Cambridge, MA, 2012); Pablo F. Gómez, The Experiential Caribbean: Creating Knowledge and Healing in the Early Modern Atlantic (Chapel Hill, 2017); Ralph Bauer and Marcy Norton, "Introduction: Entangled Trajectories: Indigenous and European Histories," Colonial Latin American Review 26 (2017): 1-17.

35 For instance: Sven Beckert, Empire of Cotton: A Global History (New York, 2014); Tonio Andrade, The Gunpowder Age: China, Military Innovation, and the Rise of the West in World History (Princeton, 2016). 